\title{
Türkiye'de İşsizliğin Ekstra Maliyeti ve İşsizlik Ödeneklerinin Maddi Yoksunluk Üzerine Etkisi
}

\author{
Öznur ÖZDAMAR ${ }^{1}$, Zeliha Semra KILINÇ ${ }^{2}$ Eleftherios Giovanis $^{3}$
}

\begin{abstract}
Özet
Isssizliğin yarattığı maddi kayıplar sebebiyle bireylerin yaşamlarında olumsuzluklara neden olduğu düşünülmektedir. Finansal kayıplar nedeniyle, işsizlerin maddi yoksunluğu bir işi olana klyasla daha yüksek olabilir. Aynı standartlarda yaşayabilmek için işsiz bireyler, çalışanlara nazaran ilave maddi desteğe ihtiyaç duyabilmekte veya ekstra maliyetlere katlanmak zorunda kalabilmektedir. Bu çalışma Türkiye'de işsizliğin maddi yoksunluk üzerine etkisini ve işsiz bireylerin maddi yoksunluğu telafi etmek veya çalışanlarla aynı yașam standardına sahip olmak için ne kadar ekstra maliyete katlanması gerektiğini ortaya koymayı amaçlamıştır. TÜiK Gelir ve Yaşam Koşulları Anketi (2013-2017) havuzlanmış yatay kesit mikro verilerinin kullanıldığı çalışmada Yaşam Standardı Yaklaşımı takip edilmiştir. Analizlerde Logit ve doğrusal regresyon modelleri tahmin edilmiştir. Bulgular, işsiz bireylerin çalışanlara kıyasla maddi yetersizlikler yüzünden daha az olasllıkla akraba ve aileleri ile sosyal aktiviteler için bir araya geldiği, daha az olasıllkla spor, sinema ve konser gibi aktivitelere para ayırabildiği ve daha az olasıllkla sadece kendileri için bir miktar parayı harcayabildiğini ortaya koymuștur. Bu bulgular bize, çalışmada Türkiye'deki ișsizlik yardım ve ödeneklerinin etkinliğini araştırmayı da düşündürmüştür. Illgili sonuçlar yapılan ödemelerin bireylerin maddi yoksunluğunu azaltmada ya da yaşam standardını iyileştirmede etkisinin önemsenmeyecek küçüklükte pozitif olduğunu göstermiştir.
\end{abstract}

Anahtar kelimeler: İssizlik, Maddi Yoksunluk, İsssizlik Ödenekleri, Gelir ve Yaşam Koşulları Anketi

Jel Kodu: I31, I32, J64

\section{Extra Costs of Unemployment in Turkey and The Effect of Unemployment Benefits on Material Deprivation \\ Abstract}

Unemployment can have undesirable effects on people's life by creating material deprivation. Due to material deprivation, living standards of the unemployed can be lower than those of the rest employed. To be able to live in the same standards, the unemployed may bear extra costs or need some extra amount of financial support compared to the employed. This study aims at revealing the effect of the unemployment on material deprivation and sheds in the light of a question that how much extra costs that the unemployed people bear to compensate material deprivation or to have the same living standards with the people employed. Living standards approach is applied using TURKSTAT Income and Living Conditions Survey (2008-2017) pooled cross sectional micro level data. Logit and the linear regression models are estimated for the analysis. The findings reveal that unemployed individuals are less likely to get together with their relatives and families for the social activities, less likely to spend money for activities such as sports, movies and concerts, and less likely to spend some money just for themselves, due to financial inadequacies, compared to the employed. These findings have also led us to investigate the effectiveness of unemployment benefits and allowances in Turkey. The relevant results show that the effect of the payments is positive but negligibly small in reducing the material deprivation of individuals or improving the standard of living.

Keywords: Unemployment, Material Deprivation, Unemployment Benefits, Income and Living Conditions Survey Jel Codes: I31, I32, J64

ATIF ÖNERisí (APA): Özdamar, Ö.., Kılınç Z.S. ve Giovanis, E. (2021). Türkiye'de İşsizliğin Ekstra Maliyeti ve İşsizlik Ödeneklerinin Maddi Yoksunluk Üzerine Etkisi. İzmir İktisat Dergisi. 36(3). 535-554. Doi: 10.24988/ije.202136303

${ }^{1}$ Doç.Dr., İzmir Bakırçay Üniversitesi, İktisadi ve İdari Bilimler Fakültesi, Menemen/IZMMİR,

EMAIL: oznurozdamar@gmail.com ORCID: 0000-0002-2188-3733

2Doktora Öğrencisi., Dokuz Eylül Üniversitesi, İktisadi ve İdari Bilimler Fakültesi, Buca/IZMMIR,

EMAIL: zeliha.semra@gmail.com ORCID: 0000-0001-9837-1587

${ }^{3}$ Dr., Marie Skłodowska Curie Proje Yürütücüsü, Aydın Adnan Menderes Üniversitesi, Nazilli İktisadi ve İdari Bilimler Fakültesi, Nazilli/AYDIN, EMAIL: giovanis95@gmail.com ORCID: 0000-0002-7492-7461 


\section{GíRiș}

2018 yllı itibariyle dünyadaki toplam işsiz sayısı 172 milyon kişi olmakla birlikte, bu sayı 2020 yllı sonunda 220 milyona çıkmıştır (ILO, 2021). 2021 yllı Haziran ayına ait Türkiye İstatistik Kurumu (TÜİK) verileri $15-64$ yaş arası işsizlik oranının \%10,6, toplam işsiz sayısının ise 3 milyon 399 bin olduğunu göstermektedir. Erkekler arasında işsizlik oranı \%9 iken, kadınlarda işsizlik oranı \%14,1 olarak gerçekleşmiştir. Genç işsizlik açısından ise oranlar daha yüksektir. Türkiye'de 15-24 yaş arası genç işsizlik oranı \%20,7 olarak gerçekleşmişken, genç kadınların $\% 26,1^{\prime} i$, genç erkeklerin ise \%17,9'u ișsizdir (TÜİK, 2020).

Gençlerin yüksek oranlarda işsiz olması gelecekte işsizliğin yaratacağı bireysel ve toplumsal sorunlar konusunda kaygı vericidir. Özelikle işsizlikle ortaya çıkan mali kaynak yetersizliğinin hem bireyin hayatında hem de yaşadığı aile ve toplumda belli problemleri beraberinde getirdiği düşünülmektedir. $\mathrm{Bu}$ problemler fiziksel ve ruhsal sağllk problemleri, ailede geçimsizlik gibi durumlar olduğu gibi, daha derinde maddi yoksunluk olarak karşımıza çıkmaktadır. Bu bağlamda işsiz bireylerin çalışanlarla aynı seviye yaşam standardına sahip olabilmeleri için katlanmaları gereken ekstra maliyet ya da diğer bir ifade ile maddi yoksunluğu yok etmede elde etmeleri gereken ilave ödenekler vardır. Bu çalışmada TÜİK "Gelir ve Yaşam Koşulları Anketi" (2013-2017) havuzlanmıs yatay kesit veri seti kullanılarak, işsizliğin maddi yoksunluk üzerine etkisi tahmin edilmiştir. Diğer bir ifade ile işsiz olan bireylerin işsiz olmayan bireylerle aynı yaşam standardına sahip olması için katlandıkları ekstra maliyet ya da ihtiyaç duyulan finansal para miktarı hesaplanmıştır. Hesaplamalar yapılırken "yaşam standardı yaklaşımı" takip edilmiş ve hesaplamaların temel aldığı analizlerde mikroekonometrik yöntemler kullanılmıştır.

Politika yapıcılar işsizliğin maddi ve manevi kayıplarını en aza indirgeyebilmek ve yeni istihdam olanakları yaratabilmek adına poli- tikalar üretmektedirler. İşsizlikle mücadele konusunda politika yapıcılar tarafından uygulamaya koyulan politikalar aktif ve pasif istihdam politikaları șeklinde ikiye ayrılmaktadır. Aktif istihdam politikaları işsiz bireylerin mesleki becerilerini geliştirerek onlara istihdam sağlama amacı taşımaktadır. Türkiye'de uygulanan aktif istihdam politikalarının başında İŞKUR'un mesleki eğitim programları, toplum yararına çalışma programları, işbaşında eğitim programları ve girişimcilik programları gelmektedir. Ayrıca yatırımları ve dolaylı olarak istihdamı artırmayı amaçlayan sigorta primi ve gelir vergisi stopajı destekleri de aktif istihdam politikaları kapsamına girmektedir. Pasif istihdam politikaları ise işsizlere gelir desteği sağlayarak yoksulluktan kurtulmalarını veya en azından yaşam standartlarını çalıştıkları döneme kıyasla aynı seviyede tutmalarını amaçlayan politikalardır. Pasif istihdam politikaları yoksulluğun etkisini hafifletme amacı güderken, aktif istihdam politikaları gibi meslek edindirme yoluyla işsizlik ve yoksulluğa son verme hedefi taşımamaktadır. Politika yapıcılarca uygulanan pasif istihdam politikalarının en yaygın olanı Türkiye'de de uygulanmakta olan işsizlik sigortası gibi parasal işsizlik yardımlarıdır. Çalışmada işsiz bireylerin çalışanlarla aynı yaşam standardına sahip olabilmesi ya da yaşanılan maddi yoksunluğun telafisi için gerekli olan parasal miktarın hesaplanmasının yanı sıra Türkiye'de ödenmekte olan işsizlik sigortası gibi ödeneklerin maddi yoksunluk üzerine etkisi de analiz edilmiştir.

Çalışma, işsiz bireylerin ihtiyaç duyduğu ekstra finansal miktarı ya da katlanılması gereken ilave maliyeti hesaplarken "yaşam standardı yaklaşımını" takip etmiş olup, bu özelliği ile Türkiye özelinde yapılacak ilk çalışmalardan biri olma niteliği taşımaktadır. Bu yöntem kullanılarak uluslararası literatürde genelde; engellilik, hanedeki çocuk sayısı gibi faktörlerin hanehalkına getirdiği ilave maliyet hesaplanmışken, işsizliğin hanehalkından ziyade bireylerin kendileri üzerinde yarattı̆̆ maddi kayıplar çok az sayıda çalışma tarafından ölçülmüştür. Bu bağlamda çalışmanın ilgili 
yazına katkılarının önemli olduğu düşünülmektedir. Çalışmanın ikinci bölümünde işsizliğin getirdiği maddi kayıp ve işsizlik ödeneklerinin maddi yoksunluk üzerine etkisini araştıran çalışmalardan bir literatür özeti sunulmuş olup, çalışmanın literatüre katkıları tartışılmıştır.

Üçüncü bölümde ise yaşam standardı yaklaşımı anlatılmakta olup, işsiz bireylerle çalışanlar arasındaki yaşam standardı farkı veya aynı yaşam standardına sahip olabilmeleri için işsizlere gereken ilave finansal destek teorik olarak ortaya koyulmuştur. Dördüncü bölüm ise ilgili analizlerde kullanılan değişkenlere ilişkin tanımlayıcı istatistikleri ve tanımlayıcı bilgileri sunmuştur. Beşinci bölüm, Türkiye'de işsizliğin maddi yoksunluk üzerindeki etkilerini, çalışanlarla aynı yaşam standardına sahip olmak için katlanmak durumunda oldukları maliyeti ve işsizlik ödeneklerinin etkilerini ölçmede kullanılan ekonometrik yöntemi anlatmıştır. Aynı bölümde ortaya konulan ampirik bulgular da tartışılmıştır. Altıncı bölüm ise çalışmanın sonuç kısmından oluşmaktadır.

\section{LITERATÜR TARAMASI}

İşsizliğin bireylerde maddi veya maddi olmayan kayıplar yarattığı literatürde sıklıkla ortaya koyulmuş bir bulgudur. $\mathrm{Bu}$ alanda yapılan ampirik çalışmalar işsizliğin yarattığı maddi kayıplardan ziyade fiziksel ve psikolojik sağlık kayıpları gibi doğrudan ekonomik olmayan etkileri (Catalano vd., 2011; Strully 2009; Burgard vd., 2007; Gallo vd. 2006; Gallo vd., 2004; Ferrie vd., 1998; Dooley vd., 1996; Turner, 1995) üzerinde yoğunlaşmıştır.

Ekonomik olmayan etkiler arasında en çok incelenen konular genel sağlık durumu, depresyon, kaygl, güvensizlik, utanç, intihar eğilimi ve kalp krizi gibi sağlık problemleriyle gelen ölüm ve felçlerdir. Örneğin işini kaybedenlerin, çalışanlara kıyasla \%15-\%30

\footnotetext{
${ }^{4}$ Ayrıca çeşitli hastalık ve rahatsızlıklar nedeniyle gerçekleşen ölümlerle ilgili olarak, işsizliğin özellikle erkeklerde felç (Franks vd., 1991) ve kroner kalp hastalığı (Tunstall-Pedoe vd.,1989) geçirme riskini
}

daha fazla depresyon ve kaygı belirtileri gösterdikleri (Catalano vd., 2011; Paul ve Moser 2009; Burgard vd., 2007), iş yerleri kapandığında işsiz kalan bireylerde ruhsal sağlık problemlerinin belirdiği (Broman vd., 1990) literatürde elde edilen bulgulara örnektir. Her gün işyerinde mesai arkadaşları ile geçirilen zamanın artık olmamasının, statü kaybı ile sosyal paylaşım ve iletişimin azalmasının bireylerde sosyal fobi ve özgüven zayıflığına yol açarak sağlık sorunlarını tetiklediği de bulunmuștur (Helliwell ve Putnam, 2004; Björklund, 1985) .

İşsizliğin ekonomik veya maddi etkilerini inceleyen çalışmalar ise (Brand, 2015; Couch vd., 2011; Cha ve Morgan 2010; Couch ve Placzek 2010; Kletzer, 1998; Couch 1998; Jacobson vd., 1993; Topel, 1990; Ruhm, 1991; Podgursky ve Swaim, 1987) işsizlikle gelen ekonomik kayıpların işsiz kalınan süre arttıkça daha da çoğaldığını, özellikle daha önce çalıșılan firmanın sanayi kolu ya da endüstri değiştirmesinin işsizlerin yeniden iş bulmasını zorlaştırdığını ortaya koymuşlardır. Yeni endüstrilerde yürütülen işlerin gerektirdiği yetenekleri sergileyemeyen bireylerin başka bir sektörde yeni bir iş bulsalar dahi, bulunan işlerin düşük ücretli olmasından bireylerin maddi yoksunluğunun ve ekonomik kayıplarının hayat boyu devam ettiği belirtilmiştir (Brand, 2015).

Topel (1990), Ruhm (1991) ve Jacobson vd. (1993) bu bireylerin ilk işlerini kaybetmeleri ile yüzde 15-40 arası gelir kaybı yaşadıklarını, bu kayıpların beşerî sermaye birikimleri, işgücü piyasası deneyimleri az olan ve nitelikli olmayan bireyler açısından daha da arttığını göstermişlerdir. Bentolila ve Ichino (2008) işsizliğin gıda harcamaları gibi temel gereksinimlere yönelik tüketimi azaltarak bireylerin yaşam standardında düşüş yaşattığını belirtmiş, Browning ve Crossley (2000) ise işsizlerin işsizlik döneminde dayanıklı mal tüketimi harcamalarını azalttığını ortaya koy-

artırdığı da tespit edilmiştir. Junankar ve Kapuscinski (1991) ile Wang (2015) benzer şekilde işsizliğin ölüm oranlarında artışa sebebiyet verdiği bulgusuna ulaşmıştır. 
muştur. Gagan ve Gagan (1990), işçi sınıfı için yaşam standardının en belirleyici faktörlerinden birinin istihdam olduğunu söylerken, Bradbury (1993) gibi hanehalklarının iyi bir yaşam standardına sahip olması için hanede işsiz bireylerin olmaması, birden fazla eve ekmek getiren bireyin olması gerektiğini vurgulamıştır. Sager ve Baskerville (1997) ise belli bir yaşam standardının veya maddi yoksunluk sınırının altında yaşamanın işsizlikle doğrudan ilişkili olduğunu belirtmiştir.

Ancak tüm bu literatür incelendiğinde, işsizlerin maddi yoksunluğu telafi etmek ve çalışanlarla aynı yaşam standardına sahip olabilmesi için ihtiyaç duyduğu parasal miktar veya katlandığı ekstra maliyet Türkiye için ampirik analizlerle ortaya koyulmamış olup, uluslararası yazında detaylı mikro verilerle analizi az sayıdadır. Örneğin Carroll (2007) Avustralya'da işsiz kalan erkeklerin çalışanlarla karşılaştırıldığında yaşamdan aynı derecede memnun olabilmeleri için katlandıkları ekstra maliyeti yıllık 42000 dolar olarak ölçmüştür.

Türkiye'de işsizliğe ilişkin yapılan çalışmalar, işsizlik faktörünün yoksulluğun en önemli belirleyicisi olduğuna (Bayram vd, 2012) ve psikolojik problemleri beraberinde getirdiğine vurgu yapmıștır (Yüksel, 2003; Kamu-Sen, 2004; Çizel vd., 2011). Topbaş (2007), 19752005 yılları arası verileri kullanarak Türkiye'de işsizliğin intihar oranlarını artırdığını VAR analizi ile ortaya koymuştur. Özetle, mevcut ulusal çalışmalar Türkiye özelinde işsizliğin yaşam standardını koruyabilmek adına yarattığı ekstra maliyeti detayl mikro verilerle ölçmemiştir. İşsizlik her ne kadar hem bireysel hem de toplumsal bir sorun olsa da toplumsal bir probleme dönüşmesinin nedeni ilk olarak bireyler üzerinde yarattığı maddi ve manevi kayıplardır. Ayrıca toplumda yaşayan her bir bireyin sosyo-ekonomik özellikler ve hanehalkı kararkteristikleri açısından birbirinden çok farklı olması, ișsizliğin her bir birey üzerinde etkisinin farklı olmasına neden olmaktadır. Bireyler yaşları, gelirleri, medeni halleri ve eğitim düzeyleri gibi sosyal ve ekonomik özellikler bakımından farklılaştığından ve bu nedenle ișsizlikten farklı șiddetlerde etkilenebileceklerinden bu faktörlerin analizlerde kontrol edilmesi gerekmektedir.

Çalışmamızda Türkiye'de işsizlik ödeneklerinin etkisi de sorgulanmış olup, ulusal literatürde detaylı mikro veriler ile maddi yoksunluk üzerine etkisi araştırılmamıştır. Uluslararası literatürde yapılan çalışmalardan örnek verilecek olursa; Pissarides (1998), işsizlik ödeneklerinin belli bir seviyeye kadar artırılmadığı müddetçe uzun vadede maddi yoksunluk kayıplarını giderici etkisinin olmayacağını vurgulamıştır. Vodopivec vd. (2003), Doğu Avrupa ülkelerinden Letonya, Bulgaristan ve Estonya'da işsizlik ödeneği alan yoksul ailelerin bu ödenekten yararlanan genel nüfus içinde payının az olmasından dolayı ödeneklerin yoksulluğu azaltmada etkisinin az olduğunu belirtmiştir. Benzer şekilde MacDonald vd. (2009) işsizlik ödeneklerinin maddi zorluğu azalttığını ama yok etmediğini göstermiştir. Ulusal literatürde Ozdamar vd. (2019) yapısal eşitlik modeli ile işsizlik ödeneklerinin sağlık ve yaşam standardı ile eşanlı ilişkisini ortaya koymuştur. Ancak bu çalışmadan farklı olarak kullanılan yaşam standardı veya maddi yoksunluk endeksi hem hanehalkı düzeyinde ölçülmüş hem de içerdiği değişkenler çamaşır makinası, televizyon, araba, banyo/tuvalet gibi maddi varlıkların sahipliğinden oluşmuştur. İşsizlik ödeneklerine veya sigortasına ilişkin yazılmış diğer ulusal eserler ise sadece ödeneğin tasviri, koșulları, uygulaması üzerine hazırlanmış olup (Kutal, 2003) bu çalışmada ele alındığı şekli ile bireysel düzeyde bir yașam standardı ya da maddi yoksunluk endeksi oluşturularak, ișsizliğin getirdiği maliyet ve işsizlik ödeneklerinin etkisi ampirik olarak incelenmemiștir.

\section{YAŞAM STANDARDI YAKLAŞIMI}

İlgili literatürde yaşam standardı yaklaşımını uygulayan çalışmaların (Zaidi ve Burchardt, 2005; Cullinan vd., 2011; Morciano vd., 2015) genellikle engelli ve engelli olmayan bireylerin aynı yaşam standardına sahip olabilmesi için ihtiyaç duyduğu finansal destek ya da katlandığı ekstra maliyeti araştırdıkları 
görülmektedir. Ancak Sen (1985)'in kapasite teorisi (capability approach) ile altını çizdiği gibi, bireylerin kendi kapasitelerini kullanma veya o kapasiteyi olușturan yeterlilikleri elde etme noktasındaki dezavantajlıkları göz önünde bulundurulduğunda sadece engelliler değil, isssizler, yoksullar ve hatta dünyanın pek çok yerinde hâlâ kadınlar maalesef dezavantajlı gruplar arasında gösterilmektedir. Türkiye'de dezavantajlı gruplardan olan işsizlerin emsalleri olan çalıșanlarla aynı yașam standardını sürdürebilmeleri ya da yaşadıkları maddi yoksunluktan kurtulabilmeleri için ihtiyaç duydukları parasal miktar ya da katlandıkları ekstra maliyet hesaplanırken yașam standardı yaklaşımı kullanılmıștır. Şekil (1), engellilerin yaşam standardı için gerek duyduğu parasal miktarı hesaplayan Zaidi ve Burchardt (2005)'ın çalışmasından alınarak işsiz ve çalışan bireyler için uyarlanmıştır.

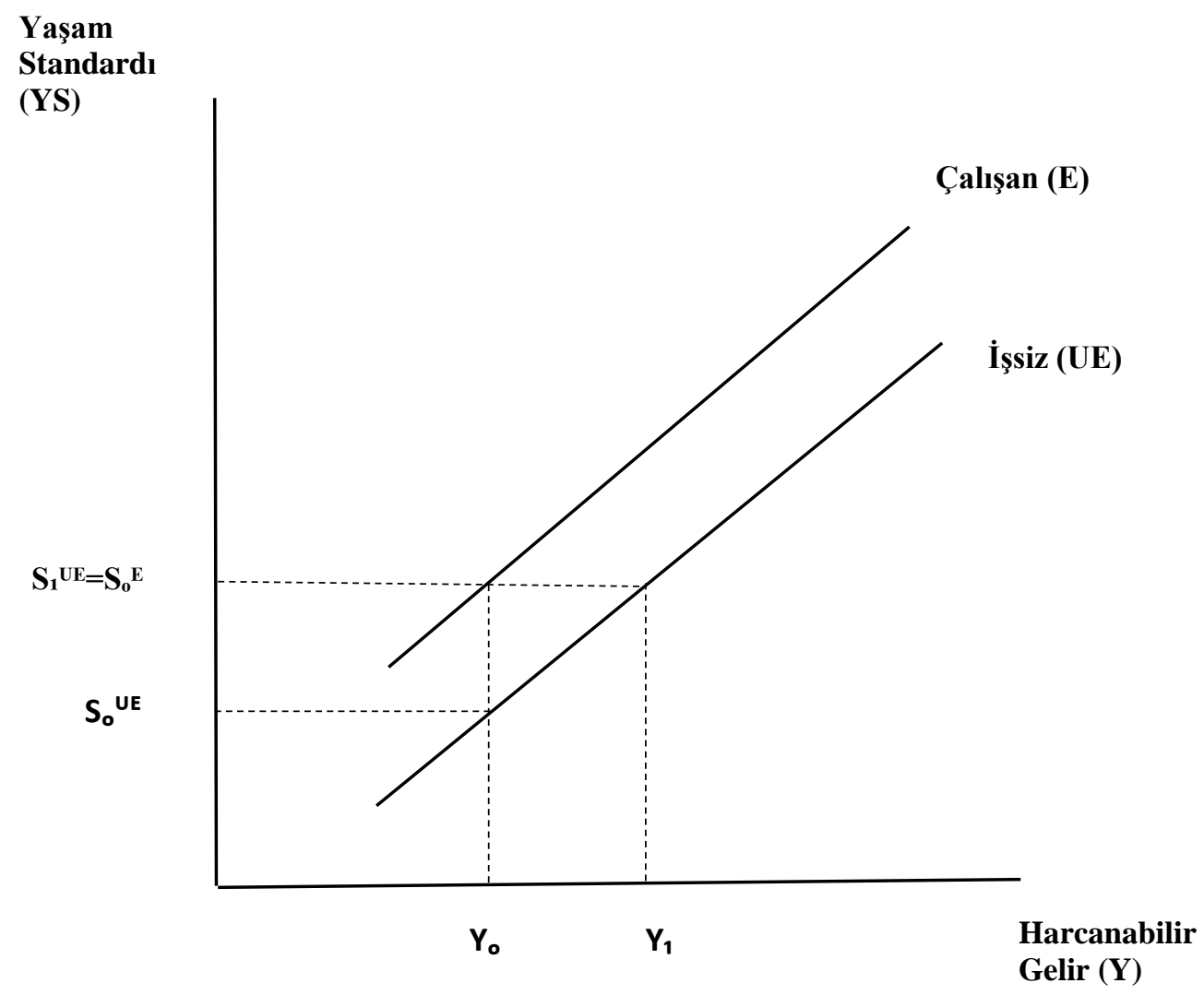

Şekil 1: İşsiz Bireyler ile Çalışanların Yaşam Standardı Karşılaştırılması Kaynak: Zaidi ve Burchardt (2005)'ın çalışmasından uyarlanmıştır

Veri gelir düzeyinde $\left(Y_{0}\right)$ işsiz bir bireyin sahip olduğu yaşam standardı düzeyi $S_{0}^{U E}$ ile gösterilmiştir. Aynı gelir düzeyinde çalışan bir bireyin yaşam standardı ise daha yüksek bir seviyede olan $S_{0}^{E}$ ile ifade edilmiştir. İşsiz bireyin, çalışan birey ile aynı yaşam standardına sahip olmasının tek yolu $Y_{1}-Y_{0}$ arası kadar ekstra gelire sahip olması ya da $Y_{1}-Y_{0}$ kadar maliyete katlanması ile mümkün olmaktadır. Bu gelir aynı zamanda maddi yoksunluğun telafisi için gerekli olan gelir düzeyidir. Şekilde görüldüğü gibi $Y_{1}$ işsiz bireyin, çalışan bireyle aynı yaşam standardına sahip olduğu gelir düzeyidir ( $S_{1}^{U E}$ $=S_{0}^{E}$ ). Şekil (1)'de $\mathrm{X}$ ekseninde yer alan harcanabilir gelir dışında tabii ki yaşam standardını etkileyen yaș, medeni hal, cinsiyet, eğitim gibi farklı bireysel karakteristikler vardır. İkiden fazla boyutlu grafik çizilerek bu faktörlerin etkisi grafik üzerinde kontrol edilemediğinden ekonometrik analiz ile işsiz 
bireylerin katlanması gereken ekstra maliyet hesaplanacaktır. Analizlerde TÜIK "Gelir ve Yaşam Koşulları Anketi” (2013-2017) havuzlanmış yatay kesit veri seti kullanılmış olup, veri setinin yapısı ve analizlere konu olan değişkenlere ait tanımlayıcı istatistikler bir sonraki bölümde anlatılmıştır.

\section{VERİ SETI VE DEĞISSTKENLER}

2013-2017 yılları arası TÜİK Hanehalkı Gelir ve Yaşam Koşulları Anketi'nde gelir, yoksulluk, sosyal dışlanma ve diğer yaşam koşullarına ilişkin göstergeler ile bireylerin demografik özellikleri, bireylerin sağlık durumu, eğitim durumu, istihdam durumu, yaşanılan konut ve çevre ile ilgili sorulara yer verilmiştir. 2013 yılında ilk kez maddi yoksunluk başlığı altında çeşitli sorular ankette yer almıştır. Yaşam standardı ya da maddi yoksunluk doğrudan anket sorusu olarak yer almadığından, diğer bir ifade ile veri setinde gözlenemeyen örtük (latent) değişken olduğundan, örtük değișkeni yaratmak için ankette maddi yoksunluk başlığ altında yer alan sorular kullanılarak bir endeks oluşturulmuştur. Bu sorular Tablo (1)'de belirtilmiştir.

Tablo 1: Yaşam Standardı Endeksinin Oluşturulmasında Kullanılan Değiş̧kenler

\begin{tabular}{|c|c|c|}
\hline $\begin{array}{l}\text { YASSAM STANDARDI ENDEKSINIIN OLUŞTURULMASINDA } \\
\text { KULLANILAN DEĞIȘKENLERE İLISSTIN ANKET SORULARI }\end{array}$ & SEÇENEKLER & DÜZENLEME \\
\hline Eskimiş giysilerinizin yerine yenisini alır mısınız? & $\begin{array}{l}\text { 1-Evet } \\
\text { 2-Hayır (maddi yetersizlik } \\
\text { nedeniyle) } \\
\text { 3-Hayır (Diğer sebepler- } \\
\text { maddi yetersizlik dışında) }\end{array}$ & $\begin{array}{l}\text { 1-Evet } \\
\text { 2-Hayır (0 değerini aldı) } \\
\text { NOT: } 3 \text { değerini alan cevaplar } \\
\text { analizlerde kullanılan veri setine } \\
\text { dâhil edilmemiștir. }\end{array}$ \\
\hline $\begin{array}{l}\text { Biri her türlü hava koşuluna uygun olmak üzere düzgün iki } \\
\text { çift ayakkabınız var mı? }\end{array}$ & $\begin{array}{l}\text { 1-Evet } \\
\text { 2-Hayır } \\
\text { 3-Hayır (Diğer sebepler- } \\
\text { maddi yetersizlik dışında) }\end{array}$ & $\begin{array}{l}\text { 1-Evet } \\
\text { 2-Hayır (0 değerini aldı) } \\
\text { NOT: } 3 \text { değerini alan cevaplar } \\
\text { analizlerde kullanılan veri setine } \\
\text { dâhil edilmemiştir. }\end{array}$ \\
\hline $\begin{array}{l}\text { Ayda en az bir kere arkadaşlarınızla/akrabalarınızla } \\
\text { yemek yemek veya bir şeyler içmek için evde veya } \\
\text { dışarıda bir araya gelir misiniz? }\end{array}$ & $\begin{array}{l}\text { 1-Evet } \\
\text { 2-Hayır } \\
\text { 3-Hayır (Diğer sebepler- } \\
\text { maddi yetersizlik dişında) }\end{array}$ & $\begin{array}{l}\text { 1-Evet } \\
\text { 2-Hayır (0 değerini aldı) } \\
\text { NOT: } 3 \text { değerini alan cevaplar } \\
\text { analizlerde kullanılan veri setine } \\
\text { dâhil edilmemiștir. }\end{array}$ \\
\hline $\begin{array}{l}\text { Spor, sinema, konser gibi boş zaman faaliyetlerine } \\
\text { düzenli olarak katılır mısınız? }\end{array}$ & $\begin{array}{l}\text { 1-Evet } \\
\text { 2-Hayır } \\
\text { 3-Hayır (Diğer sebepler- } \\
\text { maddi yetersizlik dışında) }\end{array}$ & $\begin{array}{l}\text { 1-Evet } \\
\text { 2-Hayır (0 değerini aldı) } \\
\text { NOT: } 3 \text { değerini alan cevaplar } \\
\text { analizlerde kullanılan veri setine } \\
\text { dâhil edilmemiştir. }\end{array}$ \\
\hline $\begin{array}{l}\text { Kimseye danışmak zorunda kalmadan her hafta küçük } \\
\text { bir miktar parayı kendi arzunuza göre harcar mısınız? }\end{array}$ & $\begin{array}{l}\text { 1-Evet } \\
\text { 2-Hayır } \\
\text { 3-Hayır (Diğer sebepler- } \\
\text { maddi yetersizlik dışında) }\end{array}$ & $\begin{array}{l}\text { 1-Evet } \\
\text { 2-Hayır (0 değerini aldı) } \\
\text { NOT: } 3 \text { değerini alan cevaplar } \\
\text { analizlerde kullanılan veri setine } \\
\text { dâhil edilmemiştir. }\end{array}$ \\
\hline $\begin{array}{l}\text { Evde kişisel amaçlı kullanımınız için internet erişiminiz var } \\
\text { mı? }\end{array}$ & $\begin{array}{l}\text { 1-Evet } \\
\text { 2-Hayır } \\
\text { 3-Hayır (Diğer sebepler- } \\
\text { maddi yetersizlik dişında) }\end{array}$ & $\begin{array}{l}\text { 1-Evet } \\
\text { 2-Hayır (0 değerini aldı) } \\
\text { NOT: } 3 \text { değerini alan cevaplar } \\
\text { analizlerde kullanılan veri setine } \\
\text { dâhil edilmemiștir. }\end{array}$ \\
\hline
\end{tabular}

Hanehalkı yerine birey temelli bir endeks oluşturulduğundan, bu çalışma metodolojik anlamda da ilgili literatüre önemli bir katkı sunmaktadır. Aynı sorular anketin panel veri anketinde yer almadığı için çalışmamızda her ylla ait yatay kesit veri setlerinin birleștirildiği havuzlanmış bir yatay kesit veri seti kullanılmıștır. Veri birleştirme (data merging) ve tüm analizler STATA 15 ekonometrik programı kullanılarak gerçekleştirilmiştir. Tablo (1)'de sorulan soruların ceva-bı ilgili ankette 1,2,3 şeklinde kodlanmış olup, 1; evet, 2; hayır (maddi yetersizlik nedeniyle), 3; hayır (diğer nedenlerle) şeklindedir. İşsizliğin yaşam standardında yarattığ yetersizliklerden kaynaklandığından, sorulara 
diğer nedenler yüzünden hayır denilen gözlemler analizlerde kullanılan veri setine dâhil edilmemiștir. Bir sonraki bölümde ayrıntıları ile anlatıldığı gibi, analizlerde dört farklı model kullanılmıștır. İlk modelde Tablo (1)'deki sorular kullanılarak yeni bir değişken olarak yaratılan yaşam standardı endeksi bağımlı değişkendir ve endeks nicel değerler aldığından analiz, En Küçük Kareler Yöntemi (EKKY) ile gerçekleş-tirilmiştir. Bağımlı değişkenin yaşam standardı endeksi olduğu regresyon dışında, Tablo (1)'de koyu harflerle vurgulanan sorular da diğer üç model tarafından bağımlı değişken olarak kullanılmış ve bu değişkenlerin 0 ve 1 değerini alan kukla değişken olmasından kaynaklı ilgili modeller logit modeli ${ }^{5}$ ile tahmin edilmiştir.

Yaşam standardı endeksi oluşturulurken kullanılan, ayrıca üçünün tek başına logit modellerinde bağımlı değişken olarak yer aldığı sorulara ilişkin tanımlayıcı istatistikler Tablo (2)'de sunulmuştur.

Tablo 2: İşsiz ve Çalışan Bireylerin Yaşam Standardına İlişkin Tanımlayıcı İstatistikler

\begin{tabular}{|c|c|c|c|c|c|}
\hline Panel A: İşsiz Bireyler & Gözlem S. & Ortalama & St. Sapma & Minimum & Maksimum \\
\hline $\begin{array}{l}\text { Eskimiş giysilerinizin yerine yeni giysiler alabilir } \\
\text { misiniz? (İkinci el olmayan) }\end{array}$ & 11.744 & 0,7234 & 0,4473 & 0 & 1 \\
\hline $\begin{array}{l}\text { Biri günlük kullanıma uygun olmak üzere; düzgün } \\
\text { iki çift ayakkabınız var mı? }\end{array}$ & 11.789 & 0,7561 & 0,4293 & 0 & 1 \\
\hline $\begin{array}{l}\text { Ayda en az bir kere } \\
\text { arkadaşlarınızla/akrabalarınızla yemek yemek } \\
\text { veya bir şeyler içmek için evde veya dışarıda bir } \\
\text { araya gelir misiniz? }\end{array}$ & 10.886 & 0,7333 & 0,4422 & 0 & 1 \\
\hline $\begin{array}{l}\text { Spor, sinema, konser gibi boş zaman faaliyetlerine } \\
\text { (ücret ödeyerek) düzenli olarak katılır mısınız? }\end{array}$ & 6.395 & 0,4375 & 0,4961 & 0 & 1 \\
\hline $\begin{array}{l}\text { Kimseye danışmak zorunda kalmadan her hafta } \\
\text { küçük bir miktar parayı kendi arzunuza göre } \\
\text { harcar mısınız? }\end{array}$ & 11.180 & 0,7405 & 0,4383 & 0 & 1 \\
\hline $\begin{array}{l}\text { Evde kişisel amaçlı kullanımınız için internet } \\
\text { erişiminiz var mı? (Cep telefonu, wireless, video } \\
\text { oyun konsolu, dizüstü/masaüstü bilgisayar, TV vb. } \\
\text { aracılığıyla) }\end{array}$ & 9.312 & 0,6733 & 0,4690 & 0 & 1 \\
\hline Panel B: Çalışan Bireyler & Gözlem S. & Ortalama & St. Sapma & Minimum & Maksimum \\
\hline $\begin{array}{l}\text { Eskimiş giysilerinizin yerine yeni giysiler alabilir } \\
\text { misiniz? (İkinci el olmayan) }\end{array}$ & 124.006 & 0,8531 & 0,3539 & 0 & 1 \\
\hline $\begin{array}{l}\text { Biri günlük kullanıma uygun olmak üzere; düzgün } \\
\text { iki çift ayakkabınız var mı? }\end{array}$ & 124.269 & 0,8596 & 0,3473 & 0 & 1 \\
\hline $\begin{array}{l}\text { Ayda en az bir kere } \\
\text { arkadaşlarınızla/akrabalarınızla yemek yemek } \\
\text { veya bir şeyler içmek için evde veya dışarıda bir } \\
\text { araya gelir misiniz? }\end{array}$ & 110.473 & 0,8409 & 0,3657 & 0 & 1 \\
\hline $\begin{array}{l}\text { Spor, sinema, konser gibi boş zaman faaliyetlerine } \\
\text { (ücret ödeyerek) düzenli olarak katılır mısınız? }\end{array}$ & 49.450 & 0,5880 & 0,4921 & 0 & 1 \\
\hline $\begin{array}{l}\text { Kimseye danışmak zorunda kalmadan her hafta } \\
\text { küçük bir miktar parayı kendi arzunuza göre } \\
\text { harcar mısınız? }\end{array}$ & 117.309 & 0,8784 & 0,3268 & 0 & 1 \\
\hline $\begin{array}{l}\text { Evde kişisel amaçlı kullanımınız için internet } \\
\text { erişiminiz var mı? (Cep telefonu, wireless, video } \\
\text { oyun konsolu, dizüstü/masaüstü bilgisayar, TV vb. } \\
\text { aracılığıyla) }\end{array}$ & 86.820 & 0,7909 & 0,4066 & 0 & 1 \\
\hline
\end{tabular}

Bu sorulara işsiz ve çalışan bireylerin sırasıyla nasıl cevaplar verdiğini görmek adına bu iki grup için ilgili istatistikler ayrı ayrı elde

${ }^{5}$ Logit modeli ile yapılan analizlerde, ișsiz bireylerin çalışanlara kıyasla ilgili soruya olumlu (evet) cevap vermesinin, olumsuz cevap verme (hayır) olasılığından edilmiștir. İșsiz bireylerin yașam standardına ilişkin sorulara daha az yüzdeler ile evet dedikleri görülmektedir. "Ayda en az bir kere

ne kadar az ya da fazla olduğu tahmin edildiğinden, veri setinde hayır cevabının karşılığı olan 2 değeri, 0 değerini alacak şekilde düzenlenmiştir. 
arkadaşlarınızla ya da akrabalarınızla yemek yemek veya bir şeyler içmek için evde veya dışarıda bir araya gelir misiniz?" sorusuna, işsiz bireylerin \%73,4'ü evet cevabını verirken, çalışan bireylerin \%84'ü evet demiștir. "Spor, sinema, konser gibi boş zaman faaliyetlerine düzenli olarak katılır mısınız?" sorusuna, isssiz bireylerin $\% 43,9^{\prime} u$, çalışanların ise $\% 58,9^{\prime} u$ evet demiștir. "Kimseye danıșmak zorunda kalmadan her hafta küçük bir miktar parayı kendi arzunuza göre harcar mısınız?" sorusunu ise işsiz bireylerin \%74,1'i evet olarak cevaplarken çalışan bireylerin daha büyük yüzdeyle $\% 87,8^{\prime} i$ evet cevabını vermiştir. Benzer şekilde internet kullanımı ve temel gereksinimlerden olan giyinme noktasında da işsizlerin daha dezavantajlı olduğu görülmektedir. Tabii ki burada belirtilen tanımlayıcı istatistikler yaşadıkları hanehalkının toplam geliri ve diğer sosyo-ekonomik faktörler kontrol edilmeden elde edilmiştir. Bir sonraki bölümde bu değişkenlerin kontrol edildiği durumda işsizlerin çalışanlara kıyasla ne kadar maddi yoksunluk çektiği (yaşam standartlarının ne kadar az olduğu) ya da ne kadar az olasılıkla bu sorulara evet cevabını verdikleri ekonometrik analizlerle ortaya koyulmuştur.

\section{YÖNTEM VE BULGULAR}

Yaşam Standardı endeksinin bağımlı değişken olduğu analizde kullanılan ekonometrik model (1) nolu denklem ile gösterilmiştir.

$$
Y S_{i, j, t}=\alpha+\beta Y_{i, j, t}+\delta E_{i, j, t}+b^{\prime} X_{i, j, t}+\theta_{t}+\psi_{j}+u_{i, j, t}
$$

$Y S_{i, j, t}, j$ bölgesinde, $t$ yllında yaşayan $i$. Bireye ait yaşam standardı endeksini göstermektedir. Veri seti 2013-2017 yılları arasını kapsadığından $t$ zaman indisini yani her bir yllı ifade etmektedir. Veri seti TÜIK İstatistiki Bölge

6 İBBS Düzey-1 bölgeleri şu şekildedir; TR1-İstanbul (İstanbul), TR2-Batı Marmara (Balıkesir, Çanakkale, Edirne,Kırklareli, Tekirdağ), TR3-Ege (Afyon, Aydın, Denizli, İzmir, Kütahya, Manisa, Muğgla, Uşak), TR4-Doğu Marmara (Bursa, Eskișehir, Bilecik, Kocaeli, Sakarya, Düzce, Bolu,Yalova), TR5-Batı Anadolu (Ankara, Konya,
Birimleri Sinıflandırması-1 (IBBBS-1) düzeyinde tahmin yapmaya elverişli olup veri setindeki bireylerin 12 bölgeden ${ }^{6}$ hangisinde yaşadığ 1 bilinmektedir. $j$ yaşanılan bölge indisini temsil etmektedir. $i$ ise birey indisidir. Yaşam Standardı endeksi Tablo (1)'de yer alan 6 soru kullanılarak faktör analizi yardımıyla hesaplanmıştır.

(1) nolu modelin yanı sıra, Tablo (1)'de koyu harflerle ifade edilen diğer üç soru da sırasıyla bağımlı değişken olarak kullanılmış ve üç ayrı logit modeli daha tahmin edilmiştir. $\mathrm{Bu}$ modellerde kullanılan bağımlı değişkenler sirasiyla 1- "ayda en az bir kere arkadaşlar/akrabalarla yemek yemek veya bir şeyler içmek için evde veya dışarıda bir araya gelinebilmesi", 2- "spor, sinema, konser gibi boş zaman faaliyetlerine düzenli olarak katılınabilmesi" ve 3- "kimseye danışmak zorunda kalmadan her hafta küçük bir miktar parayı bireylerin kendi arzularına göre harcamayabilmesidir". Çalıșmada bu sorular tarafından temsil edilen değișkenler sırasıyla sosyalleşme, spor ve sanatsal aktivitelere katılma ve belli miktar parayı kendi için harcayabilme olarak adlandırılmıștır. Yaşam standardı endeksinin bağımlı değişken olduğu model ile bu 3 değişseni bağımlı değişken olarak kullanan modeller işsizliğin yaşam standardı üzerine etkisini ölçmüş olup, aynı zamanda işsiz bireylerin çalışanlarla aynı yaşam standardına sahip olabilmesi için gerekli olan ilave maddi miktarı tahmin etmiştir. İşsiz bireylerin çalışanlarla aynı yaşam standardına sahip olması için katlanması gereken ekstra maliyet ya da maddi yoksunluktan kurtulması için elde etmesi gereken miktar (Zaidi ve Burchardt, 2005: 95) çalışmasından hareketle aşağıdaki formül kullanılarak hesaplanmıştır.

Karaman), TR6-Akdeniz (Antalya, Burdur, Hatay, Isparta, Mersin, Kahramanmaraș, Osmaniye), TR7-Orta Anadolu (Kırıkkale, Aksaray, Niğde, Nevşehir, Kırşehir, Kayseri, Sivas, Yozgat), TR8-Batı Karadeniz (Zonguldak, Karabük, Bartın, Kastamonu, Çankırı, Sinop, Samsun, Tokat, Çorum, Amasya), TR9-Doğu Karadeniz (Trabzon,Ordu, Giresun, Rize). 


$$
\left(\frac{d Y}{d E}\right) * \bar{Y}_{i, j, t}=-\frac{\delta}{\beta} * \bar{Y}_{i, j, t}
$$

$Y_{i, j, t}$, (1) nolu modelde bireylerin logaritmik formda harcanabilir gelirini, formüldeki $\bar{Y}_{i, j, t}$ ise veri setindeki bireylerin ortalama gelirini ifade etmektedir. $E_{i, j, t}$ bireyin istihdam statüsünü (çalışıp çalışmadığını) gösteren bir kukla değişkeni olup, 1 değerini işsiz bireyler için alırken, 0 değerini çalışanlar için almaktadır. İlgili formül ile işsizlerin katlandığı ekstra maliyeti doğru hesaplamak ve işsizliğin yaşam standardına etkisini ölçmek için yaşam standardını etkileyecek diğer faktörler de (1) nolu modelde kontrol edilmiştir. $X_{i, j, t}$ yaşam standardını etkileyen diğer sosyo-ekonomik faktörler matrisidir. Bunlar yaş, medeni hal, cinsiyet, eğitim değişkenleridir ve modele kontrol değişkeni olarak alınmıştır. Yaş değişkeni kuadratik formda ayrıca modele eklenmiştir. $\theta_{t}$ ile gösterilen zaman sabit etkileri ve $\psi_{j}$ ile ifade edilen bölge sabit etkileri de modelde kontrol edilmiştir. $u_{i, j, t}$ hata terimidir.

Tablo (3) EKKY ile tahmin edilen ilk modelin sonuçlarını göstermektedir. İşsizlerin çalışanlara göre yaşam standardının düşük olduğu, diğer bir ifade ile maddi anlamda daha yoksun oldukları bulunmuştur. İlk model kullanılarak yapılan bu tahminlere göre, maddi yoksunluğun telafisi için işsizlerin katlanması gereken ekstra maliyet aylık 1310 TL olarak hesaplanmıştır.

Tablo 3: İșsizliğin Maddi Yoksunluk Üzerine Etkisi (EKK Yöntemi)

\begin{tabular}{|c|c|}
\hline Bağımsız Değișkenler & $\begin{array}{c}\text { Bağımlı Değişken: } \\
\text { Yașam Standardı Endeksi }\end{array}$ \\
\hline Yaş & $\begin{array}{c}-0,00583^{* *} \\
(0,00235) \\
\end{array}$ \\
\hline Yaş Kare & $\begin{array}{l}-0,00001 \\
(0,00003)\end{array}$ \\
\hline Log-Gelir & $\begin{array}{c}0,22094^{* * *} \\
(0,00473) \\
\end{array}$ \\
\hline Kadın (Baz Kategori=Erkek) & $\begin{array}{c}0,13473^{* * *} \\
(0,00667) \\
\end{array}$ \\
\hline İşsiz (Baz Kategori= Çalışan) & $\begin{array}{c}-0,15586^{* * *} \\
(0,01404)\end{array}$ \\
\hline \multicolumn{2}{|l|}{ Ĕgitim (Baz Kategori= Okur Yazar Olmayan) } \\
\hline Okuryazar olup bir okul bitirmeyen & $\begin{array}{c}0,26627^{* * *} \\
(0,03503)\end{array}$ \\
\hline İlkokul Mezunu & $\begin{array}{c}0,49240^{* * *} \\
(0,02981)\end{array}$ \\
\hline Ortaokul Mezunu & $\begin{array}{c}0,86509^{* * *} \\
(0,03062)\end{array}$ \\
\hline Genel Lise Mezunu & $\begin{array}{c}1,09059^{* * *} \\
(0,03082)\end{array}$ \\
\hline Meslek Lisesi Mezunu & $\begin{array}{c}1,18558^{* * *} \\
(0,03073)\end{array}$ \\
\hline Fakülte/Yüksek Lisans/Doktora Mezunu & $\begin{array}{c}1,25685^{* * *} \\
(0,03009)\end{array}$ \\
\hline \multicolumn{2}{|l|}{ Medeni Durum (Baz Kategori= Bekâr) } \\
\hline Evli & $\begin{array}{c}0,21141^{* * *} \\
(0,00824)\end{array}$ \\
\hline Eşi Ölmüş & $\begin{array}{c}-0,11150^{* * *} \\
(0,04210) \\
\end{array}$ \\
\hline Boşanmış & $\begin{array}{c}0,0262 \\
(0,01631)\end{array}$ \\
\hline Gözlem Sayısı & 41787 \\
\hline $\mathrm{R}^{2}$ & 0,4725 \\
\hline Ekstra Maliyet & $1307 \mathrm{TL}$ \\
\hline
\end{tabular}

Not: ${ }^{*}, * *, * *$ sırasıyla \%10, \%5 ve \%1 düzeylerinde anlamlılı̆̆ı ifade etmektedir. Katsayı tahminlerinin altında parantez içinde gösterilen değerler robust (dirençli) standart hatalardır. Kukla değișken tuzağına düşmemek için cinsiyette erkek, çalışma durumunda 
çalışan, eğitim durumunda okur yazar olmayan ve medeni halde bekâr kategorileri baz kategori olarak seçilmiştir. Diğer kategorilerin katsayı tahminleri baz kategori ile kıyaslanarak yorumlanmaktadır.

Kontrol değişkenlerine bakıldığında yaşlandıkça yaşam standardının düştüğü yani maddi yoksunluğun arttığı görülmektedir. İlerleyen yaşlarda emeklilik, boş zamanın çalışmaya tercih edilmesi gibi nedenlerle bireylerin gelirleri ve beraberinde yaşam standardı düşebilmektedir. Gelir değisşkeninin pozitif katsayılı olması, parasal refahın yaşam standardını arttırdığını ortaya koymaktadır.

Cinsiyet değişkenine bakıldığında ise Türkiye'de kadınların erkeklere nazaran yaşam standardının daha yüksek olduğu görülmektedir. Eğer gelirin buna etken faktör olduğu düşünülseydi tam tersi bir sonucun elde edilmesi beklenirdi ki dünyada gelişmiş ülkelerde dahi kadınlar ve erkekler açısından ciddi gelir ve ücret eşitsizliği olduğu, kadınların erkeklere nazaran daha düşük düzeylerde gelir elde ettiği bilinen bir gerçektir. Birleşmiş Milletler tarafindan her yll hazırlanan İnsani Gelişmişlik Raporu'nun bir parçası olarak "Cinsiyet Eşitliği Endeksi" hesaplanmaktadır. 162 ülkenin sıralandığı ve Türkiye'nin tarihte ilk kez çok yüksek insani gelişmişlik sergileyen ülkeler arasına girdiği 2019 insani gelişmişlik raporunda dahi, kadınların ve erkeklerin işgücüne katılımı ile ücretler noktasında ciddi cinsiyet eşitsizliği söz konusudur? ${ }^{7}$.

Ancak gelir değişkeni, yapılan analizlerde kontrol ettiğimiz değişkenlerin başında gelmektedir ve TÜİK Gelir ve Yaşam Koşulları anketinde yaşam standardı endeksini oluşturmada kullandığımız maddi yoksunluğa ilişkin sorular dikkate alındığında çok büyük miktarlarda harcama yapmadan kadınların söz konusu sorulara evet cevabını verebileceği düşünülmektedir. Örneğin ankette maddi

${ }^{7} 2019$ yılı raporuna göre Türkiye'de erkekler \%72,6 ile kadınlardan iki kattan daha fazla işgücü piyasasına katılmaktadır. Kadınların işgücüne katılım oranı \%33,5'tir. TÜIK'in 2018 yılı "Kazanç Yapısı Araştırması" ise kadın ve erkek ücret farkının erkek lehine \%7,7 olduğunu ortaya koymuştur. Bu anlamda analiz bulguları yaşananla tutarlıdır.

${ }^{8}$ Bunu görmek adına- burada sonuçlar sunulmasa dahiişsiz olma ve cinsiyet değişkenlerinin etkileşimi yoksunluğa ilişkin sorulardan biri olan "Ayda en az bir kere arkadaşlarınızla/akrabalarınızla yemek yemek veya bir şeyler içmek için evde veya dışarıda bir araya gelir misiniz?" sorusunda diğer sorularda olduğu gibi belli bir harcama limiti belirtilmemiştir. Çok cüzi miktarlar harcanarak da gerçekleştirilebilecek ev buluşmaları için bu soruya evet denilmiş olabilir. Türkiye'de arkadaşlarla buluşma ve boş zaman aktivitelerini geçirme anlamında kadınların erkeklere kıyasla daha sosyal oldukları düşünüldügünde (gün aktiviteleri, ev gezmeleri gibi) sonuçlar akla uygundur. Ayrıca regresyonda çalışan ve çalışmayan ayrımı yapılmadığından, örneklem hem işsizleri hem de çalışanları kapsadığından, Türkiye'de iși olmayan kadınların özellikle eşlerinden elde ettiği gelirle, işsiz erkeklerden daha çok bu aktivitelere katılabildikleri düşünülmektedir8. Eğitim seviyesi arttıkça yaşam standardının yükseldiği (maddi yoksunluğun azaldığı) bulunmuştur. Üniversite ve üzeri eğitim düzeylerinde diploma sahibi olmanın diğer tüm kategorilerden daha yüksek yaşam standardı ya da daha az maddi yoksunluk getirdiği, her bir kategorinin kendinden bir önceki eğitim düzeyini gösteren kategorilerden daha yüksek sayısal değerde, pozitif ve anlamlı katsayılara sahip olduğu görülmektedir. Eğitim seviyesinin yaşam standardı ile pozitif ilişkisi ilgili literatür tarafindan da desteklenmektedir (bknz: Peet vd., 2015; Ashenfelter vd., 1999; Card, 1999).

Medeni hal değişkeni incelendiğinde, eşi ölmüş bireylerin bekârlara göre yaşam standardının daha düşük olduğu tersine evlilerin yaşam standardının daha yüksek olduğu sonucuna ulaşılmıştır. Eşi ölmüş bireyler için, eğer çocukları varsa ${ }^{9}$ çocuk bakımı gibi ekstra

regresyona eklendiğinde ișsiz kadınların işsiz erkeklerden daha yüksek olasılıkla yaşam standardı endeksini oluşturan aktivitelere katıldıkları görülmüştür.

9 Ankette çocuk sayısına karşılık gelen bir soru olmadığından bu değişken analizlerde kontrol edilememiştir. 
sorumluluk ve maddi götürü gençlere kıyasla yaşam standardında düşürücü etki yapmış olabilir. Yeniden evlenilmediği durumda eşini kaybetmenin yarattığı maddi ve manevi kaybın uzun süreli olduğu ortaya koyulmuștur (Bedard ve Deschenes, 2005). Bu alanda yapılmış önemli çalışmalardan Myers vd. (1987), ABD'de eşi ölmüş kadınların evlilere kıyasla yoksullukla daha çok mücadele ettiklerini belirtmiştir. Batı ülke örneklerinin yanı sıra, orta doğu ülkelerine yönelik yapılmış çalışmalar da özelikle kadınların eşlerini kaybettikleri durumda ekonomik olarak daha kırılgan olduklarını, Mısır'da hanehalkı reisinin kadın olduğu evlerin en az üçte birinin yoksullukla mücadele ettiğini göstermiştir (Assaad ve Rouchdy, 1999; Datt vd., 1998).

Tablo (4) "ayda en az bir kere arkadaşlar / akrabalarla yemek yemek veya bir șeyler içmek için evde veya dışarıda bir araya gelinebilmesi" değişkeninin bağımlı değișken olduğu durumda işsizliğin ekstra maliyetini ve diğer faktörlerin bu değişken üzerindeki etkilerini göstermektedir. İşsiz bireylerin çalışanlara kıyasla katlandıkları ekstra maliyet $1701 \mathrm{TL}$ olarak hesaplanmıștır.

Tablo 4: İșsizliğin Sosyalleșme Üzerine Etkisi (Logit Model/Marjinal Etkiler)

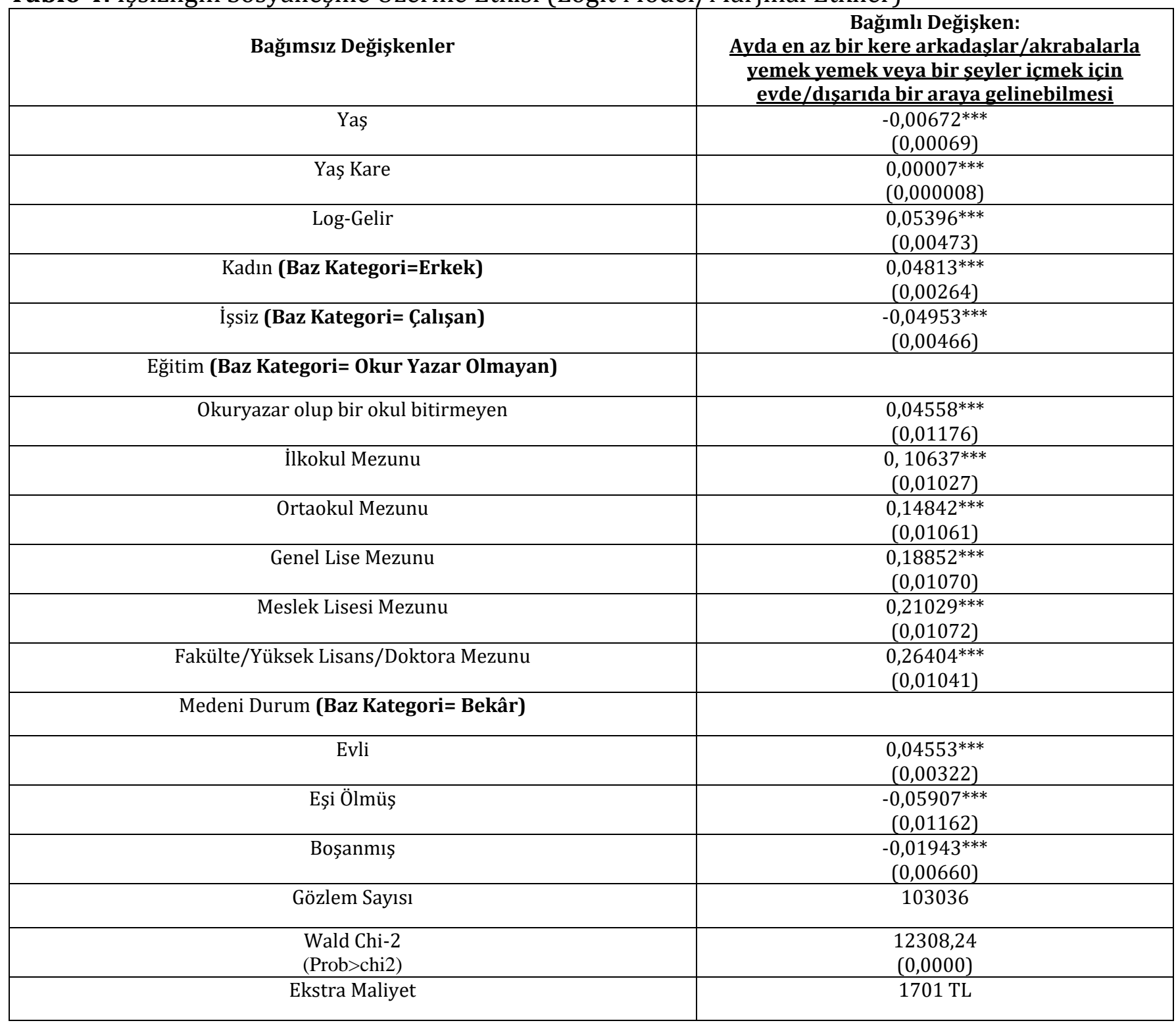

Not: $*, * *, * * *$ sırasıyla \%10, \%5 ve \%1 düzeylerinde anlamlılığı ifade etmektedir. Katsayı tahminlerinin altında parantez içinde gösterilen değerler robust (dirençli) standart hatalardır. Kukla değișken tuzağına düșmemek için cinsiyette erkek, çalıșma durumunda çalıșan, eğitim durumunda okur 
yazar olmayan ve medeni halde bekâr kategorileri baz kategori olarak seçilmiştir. Diğer kategorilerin katsayı tahminleri baz kategori ile kıyaslanarak yorumlanmaktadir.

İşsizlerin sosyalleşme olasılı̆̆ının maddi imkanlarının el vermemesinden dolayı çalışanlara kıyasla az olduğu, eğitimin sosyalleşme ile pozitif ilişkili olduğu bulunmuştur. İlkokul mezunu olmaktan yüksekokul mezunu olmaya kadar her bir kategoriye ait katsayı giderek artan oranlarda pozitif değer almaktadır. Gelir değişkeni modelde kontrol edildiğinden, eğitimli bireylerin maddi anlamda durumlarının daha iyi olması sayesinde bu sonucun elde edilmiş olabileceği söylenemez. Ancak kontrol edemediğimiz kültürel alıșkanlıklar eğitimli bireyler arasında sosyalleşme olasılığının yüksek olmasına sebep olmuş olabilir.

Diğer bağımsız değişkenlerden gelir ve yaşla birlikte sosyalleşme olasılığının arttığı, görülmektedir. Özellikle iki bireyin çalıştı̆̆ hanelerde gençlerin daha izole bir yaşantı sürdürmeleri, iş ve ev arasında belki haftasonları sadece çocukları ile zaman geçirmeye vakit bulmaları olasıdır. Belirli bir yaşın üstündeki bireylerin ise hala komşuluk, arkadaşlık ve akraba ziyaretleri gibi aktif geleneksel yaşam biçimini sürdürdüğü toplumumuzda yaş arttıkça sosyalleşmenin artması doğru bir bulgu olabilir. Özellikle belli bir yaștan sonra bireylerin kahvehaneler ya da ev gezmelerinde bir araya gelme alışkanlıkları buna örnektir. Evli bireylerin bekârlara kıyasla $\% 4,5$ daha fazla, eşi ölmüş ve boşanmış bireylerin ise sirasiyla $\% 5,9$ ve $\% 1,9$ daha az olasilıkla aile/arkadaş ve akrabalarla bir araya geldiği görülmektedir. Türkiye gibi geleneksel toplumlarda, aile toplantıları ve evlilikten kaynaklı akraba sayısındaki artış nedeniyle evlilerin bekârlara kıyasla sosyal bir ağ içinde olmaları daha olasıdır. Evli bireylerin çocuklarından da kaynaklı olarak daha sosyal, bekârların ise daha izole bir hayat yaşadıkları, evliliğin akrabalık ilişkileri ile sosyal entegrasyonu artırdığg literatürdeki bulgular arasındadır (Waite ve Gallagher, 2000; Webster vd, 1994; Hurlbert ve Acock, 1990). Boşanmış ve eşini kaybetmiş bireylerin akrabalık ilişkilerinin azalması nedeniyle böyle bir sonuç elde edildiği söylenebilir.

Tablo (5) ise "Spor, sinema, konser gibi boș zaman faaliyetlerine (ücret ödeyerek) düzenli olarak katilır misiniz?" sorusuna verilen cevabın 0 ile 1 arasında değiş̧mesi nedeniyle bir kukla değiş̧keni olan bağımlı değiş̧eni etkileyen faktörlere ilişkin tahminleri göstermektedir. İşsizlerin çalışanlara kıyasla yine daha az olasılıkla bu etkinliklere katıldıkları görülmektedir ve bu aktivitelere gerçekleştirmek için çalışanlara kıyasla ayda $976 \mathrm{TL}$ daha fazla gelire ihtiyaç duydukları ortaya koyulmuştur. Gelir değişkeninin katsayısının pozitif olması bu bulguyu destekler niteliktedir.

Eğitim ile sportif ve sanatsal faaliyetlere katılımın arttığı görülmektedir. Her bir üst eğitim kategorisinin katsayısı daha büyük, pozitif ve istatistiksel olarak anlamlıdır. Yaşla birlikte de bu faaliyetlere katılımın arttı̆̆ görülmektedir. Genç yaşlarda sportif ve sanatsal faaliyetlere katılımın daha az olduğu bulgusu ilginçtir ama bir o kadar da teknoloji ile gelen toplumsal değişimi açıklar niteliktedir. Teknolojik gelişme ile televizyon, bilgisayar ve tablet gibi ürünlerin karşısında geçirilen zaman yüzünden bedensel olarak daha az aktif bir nesilin ortaya çıktığ vurgulanmaktadır (bknz: Ogunleye vd., 2012; Vandewater vd., 2004; Marshall vd., 2004). Bilgisayar, tablet, cep telefonu gibi teknoloji kullanımının yaygınlığı ve sıklığı genç nüfusta daha az spor yapma eğilimine neden olmaktadır. "Ekran Karşısında Tembellik" (Couch Potato) olarak adlandirılan hipotezi ergen ve çocuklarda test eden çalışmalar, ekran karşısında geçirilen süre arttıkça fiziksel aktivitenin azaldığı ve obezite gibi sağlık problemlerinin yaygınlaştığı ortaya koyulmuştur (bknz: Vandewater vd., 2004). Benzer şekilde Epstein vd. (2008) yürüttükleri rassal bir deneyle televizyon izleme ve bilgisayar kullanımındaki sıklığın azalmasının çocuklarda görülen obezite problemini önlediğini ortaya koymuştur. Genç yaşlarda sanatsal aktivitelerin azlığı da yine müzik, film 
gibi boş zaman aktivitelerine internetten online olarak rahatlıkla ulaşılabilmesi ve gençlerin bu uygulamaları daha çok yapmasıdır. Medeni durum değişkenine ait kategoriler de ilginç sonuçlar ortaya koymaktadır. Evli ve boşanmış bireylerin bekârlara nazaran daha yüksek olasılıkla spor, sinema, konser gibi boş zaman faaliyetlerine katıldıkları görünürken, eşi ölmüş bireylerin daha az olasılıkla bu aktivitelere katıldığı görülmektedir. Örneklem, eşi ölmüş bireylerin genelde yaşı büyük olanları barındırdığından bu sonucun elde edilmesi normaldir. Pettee vd. (2006) özellikle eşini kaybetmiş kadın bireylerin fiziksel aktivitelere katılma olasılıklarının diğer tüm medeni hal gruplarına kıyasla daha az olduğunu ortaya koymuşlardır. Analizde kullandığımız örneklemde eşi ölmüş bireyler genelde yaşlı bireylerden oluşmakla birlikle, kadınların erkeklere kıyasla daha uzun ömre sahip olmasından kaynaklı bu bireylerin çoğunluğunu kadınlar oluşturmaktadır. Yani bulgumuz diğer ülke çalışmalarından elde edilen sonuçları destekler niteliktedir. Diğer yandan evli bireylerin bekârlara kıyasla daha çok boş zaman aktivitesi geçirmesi, çocuklarını eğlendirme amaçlı ya da daha önce belirtildiği gibi akraba/arkadaş ağının içerisinde yer alarak daha sosyal olmalarından kaynaklı olabilir.

Tablo 5: İşsizliğin Spor ve Sanatsal Aktivitelere (Ücret Ödeyerek) Katılma Durumuna Etkisi (Logit Model/Marjinal Etkiler)

\begin{tabular}{|c|c|}
\hline Bağımsız Değişkenler & $\begin{array}{c}\text { Bağımlı Değişken: } \\
\text { Spor, sinema, konser gibi bos zaman faaliyetlerine } \\
\text { (ücret ödeyerek) düzenli olarak katılınması }\end{array}$ \\
\hline Yaş & $\begin{array}{c}-0,01059^{* * *} \\
(0,00123)\end{array}$ \\
\hline Yaş Kare & $\begin{array}{l}0,00009^{* * *} \\
(0,000008)\end{array}$ \\
\hline Log-Gelir & $\begin{array}{c}0,12309^{* * *} \\
(0,00265)\end{array}$ \\
\hline Kadın (Baz Kategori=Erkek) & $\begin{array}{c}0,08091^{* * *} \\
(0,00446)\end{array}$ \\
\hline İşsiz (Baz Kategori= Çalışan) & $\begin{array}{c}-0,06484^{* * *} \\
(0,00743)\end{array}$ \\
\hline Eğitim (Baz Kategori= Okur Yazar Olmaya & \\
\hline Okuryazar olup bir okul bitirmeyen & $\begin{array}{c}0,09741^{* * *} \\
(0,02686)\end{array}$ \\
\hline İlkokul Mezunu & $\begin{array}{c}0,20730^{* * *} \\
(0,02414)\end{array}$ \\
\hline Ortaokul Mezunu & $\begin{array}{c}0,34186^{* * *} \\
(0,02436)\end{array}$ \\
\hline Genel Lise Mezunu & $\begin{array}{c}0,46545^{* * *} \\
(0,02454)\end{array}$ \\
\hline Meslek Lisesi Mezunu & $\begin{array}{c}0,52627^{* * *} \\
(0,02456)\end{array}$ \\
\hline Fakülte/Yüksek Lisans/Doktora Mezunu & $\begin{array}{c}0,65646^{* * *} \\
(0,02433)\end{array}$ \\
\hline \multicolumn{2}{|l|}{ Medeni Durum (Baz Kategori= Bekâr) } \\
\hline Evli & $\begin{array}{c}0,16713^{* * *} \\
(0,00546)\end{array}$ \\
\hline Eşi Ölmüş & $\begin{array}{c}-0,07552^{* * *} \\
(0,02227)\end{array}$ \\
\hline Boşanmış & $\begin{array}{c}0,03551^{* * *} \\
(0,00968)\end{array}$ \\
\hline Gözlem Sayısı & 48345 \\
\hline $\begin{array}{c}\text { Wald Chi-2 } \\
(\text { Prob }>\text { chi2) }\end{array}$ & $\begin{array}{l}12461,10 \\
(0,0000)\end{array}$ \\
\hline Ekstra Maliyet & $976 \mathrm{TL}$ \\
\hline
\end{tabular}

Not: $*, * *, * * *$ sırasıyla \%10, \%5 ve \%1 düzeylerinde anlamlılığı ifade etmektedir. Katsayı tahminlerinin altında parantez içinde gösterilen değerler robust (dirençli) standart hatalardır. Kukla değişken tuzağına düşmemek için cinsiyette erkek, çalıșma durumunda çalıșan, eğitim durumunda okur yazar olmayan ve medeni halde bekâr kategorileri baz kategori olarak seçilmiştir. Diğer kategorilerin katsayı tahminleri baz kategori ile kıyaslanarak yorumlanmaktadır. 


\section{Ö. ÖZDAMAR - Z.S. KILINC - E. GIOVANIS}

Tablo (6) ise "Çoğu hafta küçük bir miktar parayı kendinizi iyi hissetmek için (kendiniz için bir șey almak/yapmak gibi) harcar misinız?" sorusunun bağımlı değişken olduğu analiz sonuçlarını göstermektedir. Soruya verilen 'evet' cevabı 1, diğer sorularda olduğu 'maddi nedenlerle hayır' cevabı 0 değerini aldığından bağımlı değişken yine kukla değișkenidir. Analiz bulguları, beklendiği gibi ișsizlerin daha düşük olasılıkla bu soruya evet dediklerini ve çalışan bireylere kıyasla aynı düzeyde para harcayabilmesi için ekstra maliyete katlandığını ortaya koymaktadır. İşsiz olup olmamayı gösteren kukla değişkeninin katsayısına bakıldığında, işsizlerin \%6,9 daha az olasılıkla kendileri için harcama yapabildikleri görülmektedir. Kadınların erkeklerden daha fazla olasılıkla kendileri için harcama yaptıkları analizin bir diğer önemli bulgusudur.

Gelir arttıkça bireylerin kendileri için harcama yapma yeterliliklerinin arttığı, genç yaşlarda bu olasılığın az olduğu ancak belli bir yaştan sonra artmaya başladığı elde edilen diğer bulgular arasındadır. Bireylerin deneyimleriyle doğru orantılı olarak çalışma hayatlarının ilk yıllarında az ücret elde etmeleri ve kendileri için harcayabildikleri paranın az olması beklenen bir durumdur. Eğitim düzeylerini gösteren kategorilere ilişkin elde edilen sonuçlar da beklenildiği gibidir.

Eğitim arttıkça bireylerin kendileri için harcama yapma imkanlarının arttığı, okur yazar olmayan bireylere göre; okur yazar olan ama bir diploma sahibi olmayanların \%5,2, ilkokul mezunlarının $\% 9,4$, ortaokul mezunlarının \%12,1, lise mezunlarının \%14$\% 16$ arası ve fakülte mezunlarının \%20 olasılıkla daha çok harcama yapabildikleri ortaya koyulmuştur. Eğitimle gelen servet ve varlık artışının harcamalara da yansıdığı söylenebilir. Ayrıca literatürde, eğitimli olmanın yaşam boyu alınacak tasarruf ve finansal güvenlik kararlarında çok önemli olduğu, düşük eğitim düzeylerine sahip bireylerin finansal okur-yazarlık anlamında da yetkinliğinin az olmasından, daha plansız ve az tasarruf ettikleri ortaya koyulmuştur (Lusardi, 2008; Sherraden ve McBride, 2010). Diğer bir ifadeyle, regresyonda gelir zaten kontrol edildiğinden, belli miktar harcama yapamama durumu, para yönetiminin doğru yapılamamasından da kaynaklanabilmektedir.

Diğer bir kontrol değişkeni olan medeni haldeki kategorilere bakıldığında sadece evli olmanın katsayısının anlamlı olduğu, evli olanların bekârlara kıyasla daha fazla olasılıkla bir miktar parayı kendilerine ayırabildikleri bulunmuştur. $\mathrm{Bu}$ bulgu literatürde farklı ülke örnekleri için yapılan çalşmalarda (Heckman ve Hanna, 2015; Yuh ve Hanna, 2010) elde edilen bulgularla benzerlik göstermektedir.

Buraya kadar incelenen gerek yaşam standardı endeksinin bağımlı değişken olduğu ilk analizde, gerekse bu endeksi oluşturan değişkenlerin bazılarının bağımlı değișken olduğu diğer üç regresyon analizinde işsiz bireylerin çalışanlara kıyasla maddi anlamda yoksunluk çektikleri, daha az olasılıkla sosyalleşme ve boş zaman aktiviteleri için ödenek ayırma ya da belli bir miktar parayı kendileri için harcama imkanlarının olduğu ortaya koyulmuştur. İşsiz bireylerin işsiz kaldığı dönemde çalışanlarla aynı yaşam standardını sürdürmek için katlanmak zorunda oldukları ilave maliyetlerin olması akıllara işsizlik sigortası gibi yardım ve ödeneklerin, bireylerin yaşam standardını iyileştirmede ya da maddi yoksunluğunu azaltmada etkin olup olmadığı sorusunu getirmektedir. Bu bağlamda, ele alınan çalışma aynı zamanda işsizlik yardım ve ödeneklerinin de yaşam standardı endeksi üzerine etkisini analiz etmiştir. Tablo (7) bu analiz sonuçlarını göstermektedir. 
Tablo 6: İşsizliğin Bireylerin Kendileri İçin Belli Bir Miktar Parayı Harcayabilme Özgürlükleri Üzerine Etkisi (Logit Model/Marjinal Etkiler)

\begin{tabular}{|c|c|}
\hline Bağımsız Değişkenler & $\begin{array}{c}\text { Bağımlı Değişken: } \\
\frac{\text { Coğu hafta kücük bir miktar paranın bireyin }}{\frac{\text { kendisi için bir șey almak/yapmak için }}{\text { harcaması }}}\end{array}$ \\
\hline Yaş & $\begin{array}{c}-0,00220 * * * \\
(0,00123)\end{array}$ \\
\hline Yaş Kare & $\begin{array}{c}0,00003 * * * \\
(0,000000)\end{array}$ \\
\hline Log-Gelir & $\begin{array}{c}0,04125 * * * \\
(0,00106)\end{array}$ \\
\hline Kadın (Baz Kategori=Erkek) & $\begin{array}{c}0,00860 * * * \\
(0,00240)\end{array}$ \\
\hline İşsiz (Baz Kategori= Çalışan) & $\begin{array}{c}-0,06996 * * * \\
(0,00743)\end{array}$ \\
\hline \multicolumn{2}{|l|}{ Eğitim (Baz Kategori= Okur Yazar Olmayan) } \\
\hline Okuryazar olup bir okul bitirmeyen & $\begin{array}{c}0,05257 * * * \\
(0,01032) \\
\end{array}$ \\
\hline İlkokul Mezunu & $\begin{array}{c}0,09480 * * * \\
(0,00918)\end{array}$ \\
\hline Ortaokul Mezunu & $\begin{array}{c}0,12118 * * * \\
(0,00948) \\
\end{array}$ \\
\hline Genel Lise Mezunu & $\begin{array}{c}0,14604 * * * \\
(0,00958)\end{array}$ \\
\hline Meslek Lisesi Mezunu & $\begin{array}{c}0,16665 * * * \\
(0,00957)\end{array}$ \\
\hline Fakülte/Yüksek Lisans/Doktora Mezunu & $\begin{array}{c}0,19931 * * * \\
(0,00932)\end{array}$ \\
\hline \multicolumn{2}{|l|}{ Medeni Durum (Baz Kategori= Bekâr) } \\
\hline Evli & $\begin{array}{c}0,03424 * * * \\
(0,00269) \\
\end{array}$ \\
\hline Eşi Ölmüş & $\begin{array}{l}-0,07552 \\
(0,00886)\end{array}$ \\
\hline Boşanmış & $\begin{array}{c}0,03551 \\
(0,00529) \\
\end{array}$ \\
\hline Gözlem Sayısı & 109375 \\
\hline $\begin{array}{l}\text { Wald Chi-2 } \\
\text { (Prob>chi2) }\end{array}$ & $\begin{array}{l}10381,19 \\
(0,0000)\end{array}$ \\
\hline Ekstra Maliyet & $3145 \mathrm{TL}$ \\
\hline
\end{tabular}

Not: ${ }^{*}, * *, * * *$ sırasıyla \%10, \%5 ve \%1 düzeylerinde anlamlılığı ifade etmektedir. Katsayı tahminlerinin altında parantez içinde gösterilen değerler robust (dirençli) standart hatalardır. Kukla değişken tuzağına düşmemek için cinsiyette erkek, çalıșma durumunda çalışan, eğitim durumunda okur yazar olmayan ve medeni halde bekâr kategorileri baz kategori olarak seçilmiştir. Diğer kategorilerin katsayı tahminleri baz kategori ile kıyaslanarak yorumlanmaktadır.

Sadece işsizlik yardım ve ödeneği alan bireylerin yer aldığı örneklemle yapılan bu analizde bireyin birlikte yaşadığı hanehalkının toplam geliri de (içerisinden bireye ait işsizlik yardım ve ödenekleri çıkarıldıktan sonra) regresyon da kontrol edilmiștir. Regresyonda kontrol edilen diğer değişkenler yaşam standardını etkileyecek eğitim, cinsiyet, medeni hal, yaş gibi sosyo-ekonomik göstergelerdir.
Diğer analizlerde olduğu gibi değișen varyans probleminin yaratabileceği yanlı ve tutarsız tahminci probleminin ortaya çıkması STATA'da "robust" komutu ile elde edilen dirençli standart hatalar ile engellenmiştir.

Sonuçlar işsizlik yardım ve ödeneklerinin işsiz bireylerin yaşam standardını artırmada ya da maddi yoksunluğunu azaltmada etkin olduğunu ancak bu etkinin çok düşük olduğunu 
göstermektedir. Bu bulgudan mevcut yardım ve ödeneklerin sayısal anlamda iyileştirilmesi gerektiği sonucu çıkarılabilir. Diğer analizler ile benzer şekilde eğitim düzeyi arttıkça bireylerin yaşam standardının yükseldiği, literatürdeki diğer bulguları destekler nitelikte evli bireylerin bekârlara kıyasla yaşam standardının daha yüksek olduğu görülmektedir.

Tablo 7: İșsizlik Ödeneklerinin Maddi Yoksunluk Üzerine Etkisi (EKKY)

\begin{tabular}{|c|c|}
\hline Bağımsız Değişkenler & $\begin{array}{c}\text { Bağımlı Değissken: } \\
\text { Yașam Standardı Endeksi }\end{array}$ \\
\hline Yaş & $\begin{array}{c}0,03179 \\
(0,02413)\end{array}$ \\
\hline Yaş Kare & $\begin{array}{l}-0,00049 \\
(0,00033)\end{array}$ \\
\hline Log-Gelir (İşsizlik Yardım ve Ödenekleri Dışındaki) & $\begin{array}{c}0,33898 * * * \\
(0.02992)\end{array}$ \\
\hline Log-İşsizlik Yardımı ve Ödenekleri & $\begin{array}{l}6,36 \mathrm{e}-06^{* *} \\
(2,79 \mathrm{e}-06)\end{array}$ \\
\hline Kadın (Baz Kategori=Erkek) & $\begin{array}{c}0,05255 \\
(0,04290) \\
\end{array}$ \\
\hline \multicolumn{2}{|l|}{ Eğitim (Baz Kategori= Okur Yazar Olmayan) } \\
\hline Okuryazar olup bir okul bitirmeyen & $\begin{array}{c}0,51042 \\
(0,34561)\end{array}$ \\
\hline İlkokul Mezunu & $\begin{array}{c}0,26028 \\
(0,30157)\end{array}$ \\
\hline Ortaokul Mezunu & $\begin{array}{l}0,64220 * * \\
(0,30316)\end{array}$ \\
\hline Genel Lise Mezunu & $\begin{array}{c}0,79685 * * * \\
(0,30388)\end{array}$ \\
\hline Meslek Lisesi Mezunu & $\begin{array}{c}0,86892 * * * \\
(0,30413)\end{array}$ \\
\hline Fakülte/Yüksek Lisans/Doktora Mezunu & $\begin{array}{c}0,87559 * * * \\
(0,30376)\end{array}$ \\
\hline \multicolumn{2}{|l|}{ Medeni Durum (Baz Kategori= Bekâr) } \\
\hline Evli & $\begin{array}{c}0,16527 * * * \\
(0,04408)\end{array}$ \\
\hline Eşi Ölmüş & $\begin{array}{l}-0,09423 \\
(0,36678)\end{array}$ \\
\hline Boşanmış & $\begin{array}{c}0,14695 \\
(0,10038)\end{array}$ \\
\hline Gözlem Sayısı & 1277 \\
\hline$\overline{\mathrm{R}^{2}}$ & 0,4454 \\
\hline
\end{tabular}

Not: *,**,*** sırasıyla \%10, \%5 ve \%1 düzeylerinde anlamlılığı ifade etmektedir. Katsayı tahminlerinin altında parantez içinde gösterilen değerler robust (dirençli) standart hatalardır. Kukla değişken tuzağına düşmemek için cinsiyette erkek, çalışma durumunda çalışan, eğitim durumunda okur yazar olmayan ve medeni halde bekâr kategorileri baz kategori olarak seçilmiştir. Diğer kategorilerin katsayı tahminleri baz kategori ile kıyaslanarak yorumlanmaktadır.

\section{SONUÇ}

2013-2017 arası TÜIK "Gelir ve Yaşam Koşulları Anketi (GYKA)" verilerinden elde edilen havuzlanmış yatay kesit veri seti ile yapılan analizler işsiz bireylerin çalışanlarla aynı yaşam standardına sahip olabilmesi veya maddi yoksunluğun telafisi için katlanması gereken ilave maliyetler olduğunu göstermiştir. GYKA anketinde 2013 yllinda sorulmaya başlanan "maddi yoksunluk" başlığı altındaki sorular mikro temelli bir yaşam standardı ya da maddi yoksunluk endeksinin oluşturulmasına imkân vermiştir. İlk olarak bu endeksin bağımlı değişken olduğu regresyon analizinde, diğer faktörler kontrol altında iken, işsiz bireylerin çalışanlardan \%15,5 daha az olasılıkla iyi bir yaşam sürdükleri bulunmuştur. 
Veri setinde "maddi yoksunluk" başlığı altında bu endeksin oluşturulmasında kullanılan soruların bazıları da bağımlı değişken olacak şekilde ilave analizler de gerçekleştirilmiştir. Logit modeli kullanılarak yapılan analizlerle de işsiz bireylerin çalışanlara kıyasla yaşam standardının düşük olduğu doğrulanmıştır. Daha spesifik olarak işsiz bireylerin çalışanlara kıyasla maddi yetersizlikler yüzünden $\% 4,9$ daha az olasılıkla akraba ve aileleri ile yeme/içme gibi aktiviteler için bir araya geldiği, $\% 6,4$ daha az olasılıkla spor, sinema ve konser gibi aktivitelere para ayırabildiği ve \%6,9 daha az olasılıkla sadece kendi için bir miktar parayı harcayabildiği bulunmuştur. İşsiz bireylerin çalışanlara kıyasla aynı yaşam standardına sahip olabilmesi için ihtiyaç duyduğu finansal desteğe ilişkin bulgular, Türkiye'de verilen işsizlik yardım ve ödeneklerinin, işsizlerin maddi anlamda yoksunluklarını gidermede ne derece etkin olduğu sorusunu akıllara getirmiştir. $\mathrm{Bu}$ nedenle çalışmada ayrıca bu ödeneklerin etkinliği de araştırılmıştır.

Elde edilen sonuçlar işsizlik ödeneklerinin yaşam standardını iyileștirmede başarılı ancak etkisinin çok az olduğunu göstermiştir. $\mathrm{Bu}$ bulgular ışığında işsizlik ödeneklerinin bireylerin maddi anlamdaki yoksunluklarına önemsenmeyecek düzeyde az katkıda bulunduğu söylenebilir.

\section{KAYNAKÇA}

Ashenfelter, O., Harmon, C., ve Oosterbeek, H. (1999). A Review of Estimates of the Schooling/Earnings Relationship, with Tests for Publication Bias. Labour economics, 6(4), 453-470.

Assaad, R., ve Rouchdy, M. (1999). Poverty and Poverty Alleviation Strategies in Egypt, Cairo: American University in Cairo Press.

Bedard, K., ve Deschenes, O. (2005). Sex Preferences, Marital Dissolution, and the Economic Status of Women. Journal of Human Resources, 40(2), 411-434.

Bentolıla, S., Ve Ichino, A. (2008). Unemployment and Consumption Near and Far Away from the Mediterranean. Journal of Population Economics, 21(2), 255-280.

Björklund, A. (1985). Unemployment and Mental Health: Some Evidence from Panel Data. Journal of Human Resources, 20(4) 469-483.

Bradbury, B. (1993). Family Assistance and the Incomes of Low-Wage Families over the 1980s. Social Policy Research Centre, University of New South Wales.

Brand, J. E. (2015), The Far -Reaching Impact of Job Loss and Unemployment. Annual Review of Sociology, 41, 359-375.
Broman, C. L., Hamilton, V. L., ve Hoffman W. S. (1990). Unemployment and Its Effect on Families: Evidence from a Plant Closing Study. American Journal of Community Psychology, 18(5), 643-659.

Browning, M., ve Crossley, T. F. (2000). Luxuries are Easier to Postpone: A Proof. Journal of Political Economy, 108(5), 10221026.

Burgard, S. A., Brand, J. E., ve House J. S. (2007). Toward a Better Estimation of the Effect of Job Loss on Health. Journal of Health and Social Behavior, 48(4), 369-384.

Card, D. (1999). The Causal Effect of Education on Earnings. In Handbook of Labor Economics, Vol. 3, 1801-1863.

Carroll, N. (2007). Unemployment and Psychological Well-Being. Economic Record, 83(262), 287-302.

Catalano, R., Goldman-Mellor, S., Saxton K., Margerison-Zilka, C., Subbaraman, M., Lewinn, K., ve Anderson, E., (2011). The Health Effects of Economic Decline. Annual Review of Public Health, 32, 431-450.

Cha, Y., ve Morgan, S. L. (2010). Structural Earnings Losses and Between-Industry 
Mobility of Displaced Workers, Social Science Research, 39(6), 1137-1152.

Couch, K. A. (1998). Late Life Job Displacement. The Gerontologist, 38(1), 7-17.

Couch, K. A., Jolly, N. A., ve Placzek, D. W. (2010). Earning Losses of Displaced Workers Revisited. American Economic Review, 100(1), 572-89.

Couch, K. A., Jolly, N. A., ve Placzek, D. W. (2011). Earning Losses of Displaced Workers and the Business Cycle: An Analysis with Administrative Data, Economic Letters. 111(1), 16-19.

Cullinan, J., Gannon, B., ve Lyons, S. (2011). Estimating the Extra Cost Living for People with Disabilities. Health Economics, 20(5), 582-599.

Çizel, R.B., Güzeller, C. O., ve Mütevellioğlu, N. (2011). İşsizliğin Psikolojik Sonuçları: Antalya Örneği. Çalışma İlişkileri Dergisi, 2(1), 26-41.

Datt, G., Jolliffe, D., ve Sharma, M. P. (1998). A Profile of Poverty in Egypt: 1997. International Food Policy Research Institute (IFPRI) Working Paper, 49, 1-110.

Dooley, D., Fielding J., ve Levi, L. (1996). Health and Unemployment. Annual Review of Public Health, 17(1), 449-465

Epstein, L. H., Roemmich, J. N., Robinson, J. L., Paluch, R. A., Winiewicz, D. D., Fuerch, J. H., ve Robinson, T. N. (2008). A Randomized Trial of the Effects of Reducing Television Viewing and Computer Use on Body Mass Index in Young Children. Archives of Pediatrics \& Adolescent Medicine, 162(3), 239-245.

Ferrie, J. E., Shipley, M. J., Marmaot, M. G., Stansfeld, S. A., Smith, G. D. (1998). An Uncertain Future: The Health Effect of Threats to Employment Security and White-Collar Men and Woman. American Journal of Public Health, 88(7), 1030-1036.

Franks, P.J., Adamson, C., Bulpitt, P.F., ve Bulpitt, C.J., (1991). Stroke Death and Unemployment in London. Journal Epidemiol Community Health, $45,16-18$.

Gagan, D., ve Gagan, R. (1990). Working-Class Standards of Living in Late-Victorian Urban
Ontario: A Review of the Miscellaneous Evidence on the Quality of Material Life. Journal of the Canadian Historical Association/Revue de La Societe Historique du Canada, 1(1), 171193.

Gallo, W. T., Bradley, E., Dubin, J., Jones, R., Flaba, T., Teng, H.M., ve Kasl, S.V. (2006). The Persistence of Depressive Symptoms in Older Workers who Experience Involuntary Job Loss: Results from the Health and Retirement Survey. Journal of Gerontology, Social Sciences. 55, 131-140.

Gallo, W.T., Bradley, E., Flaba, T., Dubin, J., Cramer L., Bogardus, S., ve Kasl, S.V. (2004). Involuntary Job Loss as a Risk Factor for Subsequent Myocardial Infarction and Stroke: Findings from the Health and Retirement. American Journal of Industrial Medicine, 45(5), 408-416.

Heckman, S.J., ve Hanna, S.D. (2015). Individual and Institutional Factors Related to LowIncome Household Saving Behavior. Journal of Financial Counseling and Planning, 26(2), 187199.

Helliwell, J. F., ve Putnam, R. D. (2004). The Social Context of Well-Being. Philosophical Transactions of the Royal Society of London. Series B: Biological Sciences, 359(1449), 14351446.

Hurlbert, Jeanne S., ve Acock, A.C (1990). The Effects of Marital Status on the Form and Composition of Social Networks. Social Science Quarterly, 71(1), 163-174.

ILO (2019). World Employment Social Outlook: Trends 2019. International Labor Office, Genova. ISBN 978-92-2-132952-7.

Jacobson, T., Vredin A., ve Warne, A. (1993). Are Real Wages and Unemployment Related?. IIES.

Junankar, P. N., ve Kapuscinski C. A. (1991). Aboriginal Employment and Unemployment: An Overview. Economic Papers, 10 (4), 30-43.

KAMU-SEN (2004). İstihdam, İşsizlik ve Ücret Sorunlarına Çözüm Arayışları. Türkiye Kamu Sen AR-GE Yayınları, Yayın No: 10, Ankara. 
Kletzer, L. G. (1998). Job Displacement. Journal of Economic Perspectives, 12(1), 115-136.

Kutal, M. (2003). Türk İşsizlik Sigortasında Sigortalılara Sağlanan Yardımlar ve Bunları Yapmakla Görevli Resmî Kurumlar, İșsizliğin İş Hukuku ve Sosyal Güvenlik Hukuku Açısından Sorunları Semineri. Kamu-İș Yayınları, Ankara.

Lusardı, A. (2008). Household Saving Behavior: The Role of Financial Literacy, Information, and Financial Education Programs No. w13824, National Bureau of Economic Research.

Macdonald, M., (2009). Income security for Women: What About Employment Insurance? Public Policy For Women In Canada: The State, Income Security and Labour Market Issues, (Ed. M.G. Cohen ve J. Pulkingham), Toronto: University of Toronto Press, 251-270.

Marshall, S. J., Biddle, S. J., Gorely, T., Cameron, N., ve Murdey, I. (2004). Relationships between Media Use, Body Fatness and Physical Activity in Children and Youth: A Meta-Analysis. International Journal of Obesity, 28(10), 12381246.

Morciano, M., Hancock, R. M., ve Pudney, S. E. (2015). Birth-Cohort Trends in Older-Age Functional Disability and Their Relationship with Socio-Economic Status: Evidence from a Pooling of Repeated Cross-Sectional Population-Based Studies for the UK. Social Science \& Medicine, 136, 1-9.

Myers, D. A., Burkhauser, R. V., ve Holden, K. C. (1987). The Transition From Wife To Widow: The Importance of Survivor Benefits To Widows. Journal of Risk and Insurance, 54(4), 752-759.

Ogunleye, A. A., Voss, C., ve Sandercock, G. R. (2012), Prevalence of High Screen Time in English Youth: Association with Deprivation and Physical Activity. Journal of Public Health, 34(1), 46-53.

Ozdamar, O., Grovanis, E., ve Özdaş B. (2019). The Effect of Unemployment Benefits on Health, Living Standards and Unemployment in Turkey: Evidence from Structural Equation Modelling and Regression Discontinuity
Design. SSRN Working Papers, https://papers.ssrn.com/sol3/papers.cfm?abs tract_id=3574286, (02.10.2019).

Paul, K. I., ve Moser, K. (2009). Unemployment Impairs Mental Health: Meta-Analyses. Journal of Vocational Behavior, 74(3), 264-282

Peet, E. D., Fink, G., ve Fawzi, W. (2015). Returns to Education in Developing Countries: Evidence from the Living Standards and Measurement Study Surveys. Economics of Education Review, 49, 69-90.

Pettee, K.K., Jennifer S. B., Andrea M. K., Robert B., Caroline R. R., Lisa H. C., ve Suzanne S. (2006). Influence of Marital Status on Physical Activity Levels among Older Adults. Medicine \& Science in Sports \& Exercise 38, no. 3: 541-546.

Pissarides, C. A. (1998). The Impact of Employment Tax Cuts on Unemployment and Wages: The Role of Unemployment Benefits and Tax Structure. European Economic Review, 42(1), 155-183.

Podgursky, M., Swaim, P. (1987), Job Displacement and Earnings Loss: Evidence from the Displaced Worker Survey. ILR Review, 41(1), 17-29.

Ruhm, C. J. (1991), Are Workers Permanently Scarred by Job Displacement. The American Economic Review, 81(1), 319-324.

Sager, E. W., ve Baskerville, P. (1997). Unemployment, Living Standards, and the Working-class family in Urban Canada in 1901. The History of the Family, 2(3), 229-254.

Sen, A. K. (1985). Commodities and Capabilities, Professor Dr. P. Hennipman Lectures in Economics, Amsterdam, New York, NorthHolland: Elsevier Science.

Sherraden, M. S., ve Mcbride, A. M. (2010). Striving to Save: Creating Policies for Financial Security of Low-Income families. University of Michigan Press.

Strully, K. W. (2009). Job Loss and Health in the US Labor Market. Demography, 46(2), 221-246.

Topbaş, F. (2007), İşsizlik ve İntihar İlişkisi: 1975-2005 VAR Analizi. Karamanoğlu 
Mehmetbey Üniversitesi Sosyal ve Ekonomik Araştırmalar Dergisi, 2007(2), 161-172.

Topel, R. (1990). Specific Capital and Unemployment: Measuring the Costs and Consequences of Job Loss. In CarnegieRochester Conference Series on Public Policy, Vol. 33,181-214, North-Holland.

Tunstall-Pedoe H., Smith W. C. S, Crombie I. K., ve Tavendale R. (1989). Coronary Risk Factor and Lifestyle Variation Across Scotland: Results From the Scottish Heart Health Study. Scottish Medical Journal, 34:556-60.

Turner, J. B. (1995). Economic Context and the Health Effect of Unemployment. Journal of Health and Social Behavior, 36, 213-229.

TÜİK (2020). İşgücü İstatistikleri: Ocak 2020 http://tuik.gov.tr/PreHaberBultenleri.do?id=3 3785_(11.04.2020).

Vandewater, E. A., Shim, M. S., ve Caplovitz, A. G. (2004). Linking Obesity and Activity Level with Children's Television and Video Game Use. Journal of Adolescence, 27(1), 71-85.

Vodopivec, M., Worgotter, A., ve Raju, D. (2003). Unemployment Benefit Systems in Central and
Eastern Europe: A Review of the 1990s. Washington DC: World Bank, Social Policy Discussion Paper, (0310).

Waite, L., ve Gallagher, M., (2000). The Case for Marriage, New York, Random House.

Wang, L. (2015). Fertility and Unemployment in a Social Security System. Economics Letters, 133(C), 19-23.

Webster, S. W., Benson, D. E., ve Spray, S. L. (1994). Gender, Marital Status and Social Support. Sociological Focus, 27(2), 131-146.

Yuh, Y., Hanna, S. D. (2010). Which Households Think They Save? Journal of Consumer Affairs, 44(1), 70-97.

Yüksel, İ. (2003). İşsizliğin Psiko-Sosyal Sonuçlarının İncelenmesi (Ankara Örneği). Cumhuriyet Üniversitesi İktisadi ve İdari Bilimler Dergisi, 4 (2), 21-38.

Zaidi, A., ve Burchardt, T. (2005). Comparing Incomes When Needs Differ: Equivalization for the Extra Costs of Disability in the UK. Review of Income and Wealth, 51(1), 89-114. 